$\mathrm{Oz}$

Volume 4

Article 10

$1-1-1982$

The Anti-Cruelty Society

Stanley Tigerman

Follow this and additional works at: https://newprairiepress.org/oz

c) (i) $\Theta($

This work is licensed under a Creative Commons Attribution-Noncommercial-No Derivative Works 4.0 License.

Recommended Citation

Tigerman, Stanley (1982) "The Anti-Cruelty Society," Oz: Vol. 4. https://doi.org/10.4148/2378-5853.1041

This Article is brought to you for free and open access by New Prairie Press. It has been accepted for inclusion in Oz by an authorized administrator of New Prairie Press. For more information, please contact cads@k-state.edu. 


\section{The Anti-Cruelty Society}

\section{Chicago, Illinois}

Stanley Tigerman

The program called for a second generation addition to a 1933 building designed in "Chicago World's Fair Moderne" with a 1953 appendage done in "International Style Modern." The existing complex's intrinsic architectural message was hermetically institutional; it supported euthanizing attitudes. The Society wished to change that image, replacing it with one concerned with adoption. Thus, semiotically speaking, the new building is a sign, a billboard, that is intended to advertise the new message. The principal elevation recalls the traditional form of apartments over a store. Above storefront windows (the old "doggie in the window" trick), the fenestration is comprised of double-hung sash. The exterior is clad in horizontal aluminum siding, prefinished grey with white trim. The entrance is marked by a Palladian cutout, a key to a can of dog food and windows like the cheeks of a basset hound.

1. South elevation.

2. La Salle elevation.

3. Ground level plan.

4. Southeast axonometric.

5. View from La Salle and Grand.
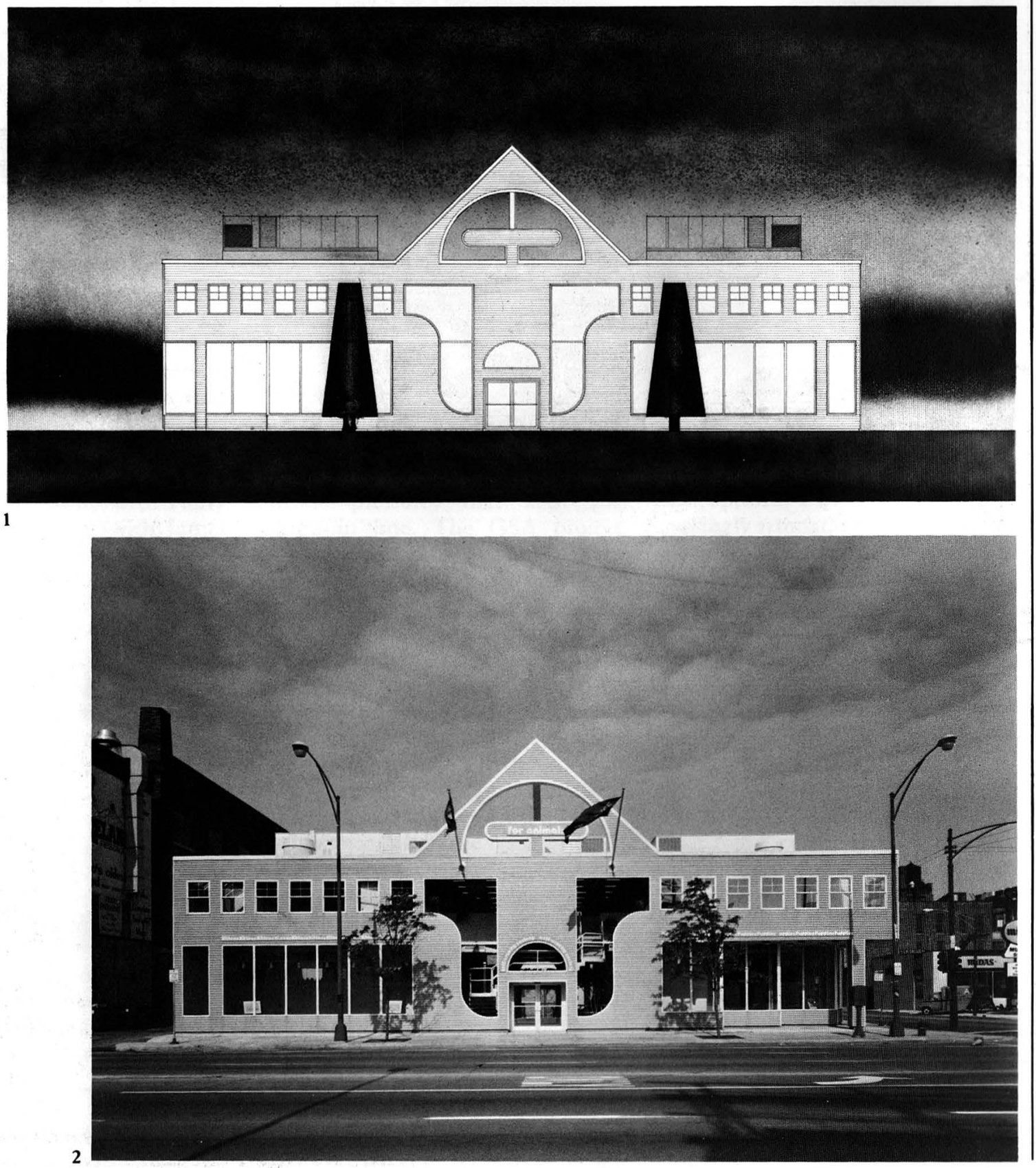

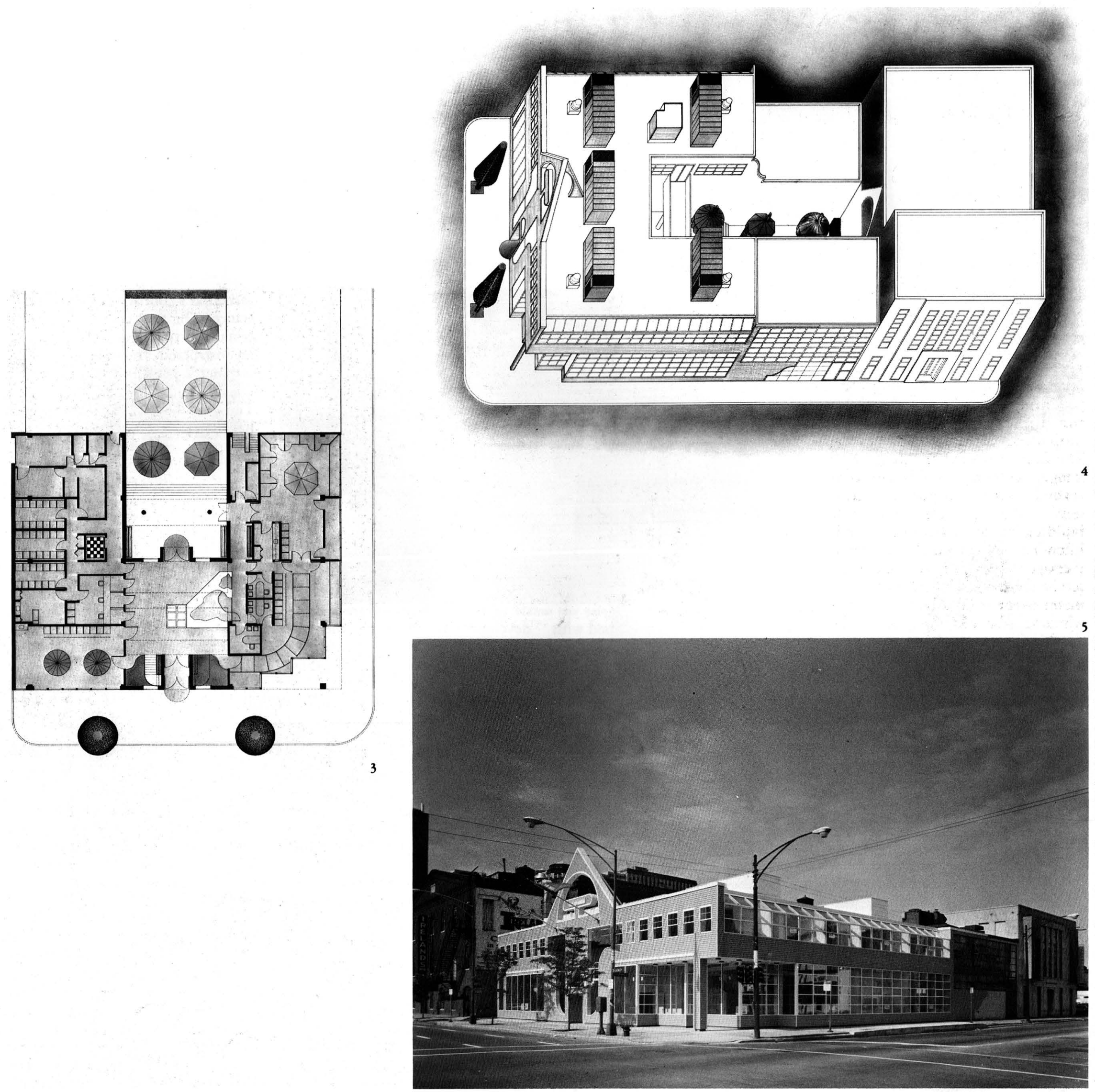